University of New Hampshire

University of New Hampshire Scholars' Repository

$12-9-2016$

\title{
Creating Communities of Culturally Relevant Critical Teacher Care
}

\author{
Elyse Hambacher \\ University of New Hampshire, elyse.hambacher@unh.edu \\ Elizabeth Bondy \\ University of Florida
}

Follow this and additional works at: https://scholars.unh.edu/educ_facpub

Part of the Education Commons

\section{Comments}

This is an Author's Original Manuscript of an article published by Taylor \& Francis in Action in Teacher Education on 09 Dec 2016, available online: http://www.tandfonline.com/10.1080/01626620.2016.1226206.

\section{Recommended Citation}

Hambacher, E. \& Bondy, E. (2016). Creating communities of culturally relevant critical teacher care. Action in Teacher Education, 38(4), 327-343. http://www.tandfonline.com/10.1080/01626620.2016.1226206

This Article is brought to you for free and open access by the Education at University of New Hampshire Scholars' Repository. It has been accepted for inclusion in Education Scholarship by an authorized administrator of University of New Hampshire Scholars' Repository. For more information, please contact Scholarly.Communication@unh.edu. 


\begin{abstract}
This paper draws on the literature on effective African American teachers of African American students to investigate the enactments of culturally relevant critical teacher care (CRCTC) in two fifth-grade teachers' classrooms in a large, urban school district. Using interview and observation data, the findings illustrate the teachers' knowledge of the constraints upon their students' futures. This knowledge catalyzed their enactment of a particular kind of care designed to prepare their students with the dispositions, knowledge, and skills to achieve flourishing lives. The teachers' practices illustrate classroom spaces ripe for high quality teaching, learning and liberation of students of color. The study reveals the transformative potential of teacher care explicitly linked to a larger social justice agenda.
\end{abstract}

This is an Author's Original Manuscript of an article published by Taylor \& Francis in Action in Teacher Education on 09 Dec 2016, available online: http://www.tandfonline.com/10.1080/01626620.2016.1226206. 


\section{Creating Communities of Culturally Relevant Critical Teacher Care}

The connection between teaching and caregiving has been long understood by exemplary teachers of African American students (Foster, 1997; Irvine, 2002; Ladson-Billings, 1994; Murrell, 2001). Children must believe their teachers care about them, and they draw this conclusion based on the teacher's behavior (Case, 1997; Delpit, 1995; Noddings, 1984). Therefore, teachers who intend to be effective with African American students must enact care, not simply proclaim it (Gay, 2010; Ware, 2006). In this paper we take up Irvine’s (2001) challenge to investigate "the complexity of a term that seems so simple — care" (p. 8). In doing so, we rely on Roberts' $(2009,2010)$ notion of culturally relevant, critical teacher care (CRCTC). CRCTC is fueled by particular principles, directed toward particular outcomes, and enacted in particular ways, each of which we expand upon in this study of two elementary teachers who enact CRCTC for their students of color.

\section{Culturally Relevant Critical Teacher Care: A Review of Literature}

Roberts' $(2009,2010)$ terminology — culturally relevant critical teacher care - is based on her synthesis of other scholars' discussions of care for students of color and her dissertation research that revealed racialized differences between European American and African American teachers' definitions and enactments of care. She built on other scholars' discussions of culturally relevant care (Gomez, Allen \& Clinton, 2004; Irvine, 2002; Noddings, 1992, 2002) by adding an explicitly political component. In doing so, Roberts (2009) intended to disrupt the "mythology of a homogenous European American "community of care"” (p. 29) and highlight the particular qualities of care necessary to assist in transforming systemic racism in schools and the larger American society.

This is an Author's Original Manuscript of an article published by Taylor \& Francis in Action in Teacher Education on 09 Dec 2016, available online: http://www.tandfonline.com/10.1080/01626620.2016.1226206. 
In Noddings' (1984) early writing on care, she explained that a caring relation between teacher and students exists if and only if the students believe that the teacher cares for them. That is, care does not exist unless the "cared for" confirms that they experience it. In her later writing, she explained, "When we care, we consider the other's point of view, his objective needs, and what he expects of us" (Noddings, 2013, p. 24), and the understandings teachers gain from these considerations shape their practice of care. Given the diverse backgrounds and perspectives represented in U.S. schools, Noddings (1992) recognized the challenge of effectively enacting care with children whom they may perceive as "strangers." Clearly, she was aware that care and caring interactions did not have a universal nature; what is perceived as care and the purposes of care differ among cultural groups. In short, she recognized the cultural relevance of care.

Further problematizing the enactment of care between teachers and students, Noddings noted the difficulty of "knowing another's nature, needs, and desires when one party holds power over the other or is a member of a group that has historically dominated another" $(1992$, p. 3). Of particular relevance to this paper, the history of racial dominance and subjugation in the U.S. has generated policies, practices, and systems that shape the thinking and practice of teachers and students in ways of which they are often unaware. As Beauboeuf-LaFontant (1997) explained about the Black teachers she studied, caring appeared as a demonstrated concern for students' wellbeing tied to concrete action, not simply feelings or words. In this way, their caring was a form of activism that challenged students' subordinated positions (Beauboeuf-LaFontant, 2005). From this perspective, caring for students, according to Beauboeuf-LaFontant, can be viewed as an act of social justice.

This is an Author's Original Manuscript of an article published by Taylor \& Francis in Action in Teacher Education on 09 Dec 2016, available online: http://www.tandfonline.com/10.1080/01626620.2016.1226206. 
Acosta (2013) drew similar conclusions in a recent study of Black teachers nominated by community members as exemplary. She found that central to the educators' demonstrations of care was a conscious understanding of the political, cultural, economic, and social implications of education for African American children, families, and communities. The participants in Acosta's study enacted care from a culture-centered perspective similar to Rolon-Dow's (2005) articulation of "color(full) critical caring" which recognized the sociopolitical circumstances of middle school Latino girls. This theorizing, as well as studies by Beauboeuf-LaFontant (1997, 1999, 2002), Noblit (1993) and Siddle-Walker (1993), offers an important conceptual shift in what it means to care by focusing on educators' responsibility for equity-focused goals. These authors revealed the transformative potential of teacher care by drawing on African American educator perspectives that explicitly link teachers' caring behaviors with a larger social justice agenda. In short, care is a powerful pedagogical tool necessary for student success and the uplift of the African American community (Acosta, 2013). It is a fundamental element of culturally relevant teaching, defined by Ladson-Billings (1994) more than 20 years ago.

Ladson-Billings (1994) explained that the purpose of culturally relevant teaching is to empower students "intellectually, socially, emotionally, and politically by using cultural referents to impart knowledge, skills, and attitudes" (p. 382). In this early work, she pointed to culturally relevant teaching as based on a deep valuing of and respect for students' cultural knowledge and performance styles and an equally deep commitment to uplifting individual African American students and the African American community at large. CRCTC may be viewed as a core component of a kind of teaching that Ladson-Billings called "culturally relevant" and Beauboeuf-LaFontant (1999) called "politically relevant," to highlight its political and historical dimensions that are often overlooked in recent writing about culturally relevant This is an Author's Original Manuscript of an article published by Taylor \& Francis in Action in Teacher Education on 09 Dec 2016, available online: http://www.tandfonline.com/10.1080/01626620.2016.1226206. 
teaching (Fasching-Varner \& Dodo Seriki, 2012). We turn next to an overview of the ideological principles that undergird CRCTC and the outcomes it is intended to accomplish. Both lay the groundwork for the findings of a study of the enactments of CRCTC identified in two elementary classrooms in a large, urban school district.

\section{Culturally Relevant Critical Teacher Care: Guiding Principles and Goals}

Drawing primarily from the work of scholars of color, we have synthesized three ideological principles that we believe undergird culturally relevant critical teacher care. It is important to clarify these principles because as King (1991) asserted, without intentional explication of the ideology that guides practice, teachers may maintain an impaired consciousness (“dysconsciousness") which preserves ignorance concerning racism in the contemporary U.S., including, of course, in U.S. schools. As Applebaum (2010) has pointed out, this "well-intentioned" racism is deeply entrenched in the white psyche and "influences [the teacher's] behavior in subtle yet pernicious ways" (p. 11). In order to cultivate CRCTC in educators for whom it is not intuitive, its guiding principles must be understood. The three principles include political clarity (Bartolomé, 2009; Beauboeuf-LaFontant, 1997, 1999, 2002; Darder, 2015; Freire, 1970); critical hope (Beauboeuf-LaFontant, 2002; Duncan-Andrade, 2009; Freire, 2002); and asset-based thinking (Bartolomé, 2009; Gorski, 2011, 2014; Valencia, 1997; 2010). Taken together, these principles crystallize desired outcomes and fuel the rigorous, colorconscious, political, authoritative caring that Roberts called CRCTC.

Political clarity. Scholars who claim the importance of teachers' political clarity to their ability to teach African American students typically refer to Freire's (1985) discussion of the phrase. Teachers who have political clarity recognize the long history of unequal power relations among various social and cultural groups and aim to prepare students to confront society's This is an Author's Original Manuscript of an article published by Taylor \& Francis in Action in Teacher Education on 09 Dec 2016, available online: http://www.tandfonline.com/10.1080/01626620.2016.1226206. 
injustices. That is, they are clear about the widespread existence of societal injustice, recognize that injustice is typically reproduced in schools, and maintain a commitment to an active struggle for justice in and outside of school while meeting skill and content goals. Although teachers' political clarity will not necessarily compensate for structural inequalities that students face outside the classroom, they still strive to help students "understand and undermine their subordination" (Bartolomé, 2009, p. 342). Furthermore, caring for students “means discussing such insights [about domination and subordination] with them, not withholding knowledge from them" (Beauboeuf-LaFontant, 2002, p. 80). Siddle-Walker (1993) referred to this kind of teaching practice among pre-integration era Black teachers as "colortalk" in which teachers acknowledged to their Black students the material realities and consequences of race in everyday life. In contrast, Alice McIntryre (1997) described the politically unclear caring of several white female students in a preservice teacher preparation program and noted its potential danger to their students. The preservice teachers, proclaiming their care for their students, were inclined to pity them, blame them for behavior they viewed as unruly, and attempt to save the students from what the novices viewed as their own and their families' deficiencies. This kind of destructive caring can serve only to sustain the opportunity gap that has cemented in place the underachievement of students of color (Gorski, 2014).

Critical hope. Along with political clarity, critical hope drives CRCTC. Freire spoke often of the importance of hope in a world that can appear shameful and corrupt: "I am a teacher full of the spirit of hope, in spite of all the signs to the contrary" (in Darder, 2015, p. vi). In his book, Pedagogy of hope, Freire (2002) explained, "I do not understand human existence, and the struggle needed to improve it, apart from hope and dream...I am hopeful, not out of mere stubbornness, but out of an existential, concrete imperative" to transform the world (p. 8). This is an Author's Original Manuscript of an article published by Taylor \& Francis in Action in Teacher Education on 09 Dec 2016, available online: http://www.tandfonline.com/10.1080/01626620.2016.1226206. 
Duncan-Andrade (2009) expanded on Freire's writing about hope in his essay inspired by Tupac Shakur's metaphor about roses that grow in concrete. He described "an audacious hope that stares down the painful path; and despite the overwhelming odds against us making it down that path to change, we make the journey again and again because there is no other choice" (p. 191). Duncan-Andrade's critical or audacious hope is an active hope, that, like the roses that grow out of the cracks in concrete, has the "strength and tenacity to reach for the sun" (p. 186).

Welch (1990) tied hope to an ethic of risk that she identified in the writing of Black women authors who wrote of ongoing struggles against injustice:

Within an ethic of risk, actions begin with the recognition that far too much has been lost and there are no clear means of restitution. The fundamental risk constitutive of this ethic is the decision to care and to act although there are not guarantees of success... It is an ethos in sharp contrast to the ethos of cynicism that often accompanies a recognition of the depth and persistence of evil. (p. 68)

As Beauboeuf-LaFontant (2002) concluded, the "hopefulness of the ethic of risk keeps people from falling into the numbness and self-absorption of despair" (p. 84) as they work for justice. Whether we refer to it as hope or risk, the force these authors have described is tightly linked to a deep sense of responsibility for the collective wellbeing of humanity.

Asset-based thinking. Culturally relevant, critical teacher care is also driven by a respect for and valuing of students' knowledge, resources, and ability to excel. Siddle-Walker's (1993) research revealed that good Black teachers of Black youth during the segregation era were guided by an unflinching belief in their students' intellectual ability. Gonzalez, Moll, and Amanti's (2005) work on funds of knowledge is an example of an asset-based approach that maintains "people are competent, they have knowledge, and their life experiences have given This is an Author's Original Manuscript of an article published by Taylor \& Francis in Action in Teacher Education on 09 Dec 2016, available online: http://www.tandfonline.com/10.1080/01626620.2016.1226206. 
them that knowledge” (p. x). Similarly, Yosso's (2006) discussion of community cultural wealth highlights the many kinds of resources, or assets, that children, often viewed as deficient, bring with them to school. Research has demonstrated that when educators focus on assets, rather than deficits, student success increases (Comber \& Kamler, 2004; Rios-Aguilar, 2010).

Asset-based thinking stands in stark contrast to the deficit ideology (see Gorski, 2011; Valencia, 1997, 2010) that "still runs rampant in many schools, despite the abstraction that 'all children can learn'” (Sleeter, 2004, p. 133). Teachers with asset-based perspectives recognize, value, and utilize the knowledge, experiences, and abilities that students bring with them to the classroom (Darling-Hammond, 2008). Bartolomé (2009) linked asset-based thinking to political clarity when she argued that developing political clarity requires that one recognize that students from marginalized backgrounds have historically been perceived as deficient. She challenged educators to think about how deficit ideology affects their beliefs and practices and to remain vigilant so as to avoid allowing deficit-based thinking to infect their practice and, consequently, their students.

These ideological principles_-political clarity, hope (laced with responsibility), assetbased thinking - together drive the equity agenda of teachers who enact CRCTC. Striving to improve lives and uplift communities, teachers employ particular strategies. Within the context of a study designed to examine teachers' beliefs and practices related to student behavior issues, two elementary teachers spoke with urgency about the skills they needed to teach their students to help them navigate a system where the odds are stacked against them.

\section{Methods}

Although the study was initially designed to investigate how exemplary teachers of students of color responded to student behavior they viewed as difficult to manage, preliminary This is an Author's Original Manuscript of an article published by Taylor \& Francis in Action in Teacher Education on 09 Dec 2016, available online: http://www.tandfonline.com/10.1080/01626620.2016.1226206. 
interview and observation data indicated that the teachers did not view their students' behavior as difficult to manage. In fact, the data revealed multiple examples of CRCTC. Hence, the guiding question for the study became: How do elementary teachers enact culturally relevant critical care for their students of color?

The study was guided by a constructivist perspective that views knowledge as being constructed by people as they engage with events, people, and objects (Crotty, 1998). Through a dynamic knowledge-construction process, people make sense of their experience (Hatch, 2002). In order to document and explore teachers' enactments of care, we sought to gain insight into their understandings about their students and their work and responsibilities as teachers. This constructivist lens guided our decisions about research methods (Koro-Ljungberg, YendolHoppey, Smith, \& Hayes, 2009). Following an introduction to the study setting and participant selection, we explicate the research methods.

\section{Context and Participant Selection}

Dundee Elementary School (pseudonym) serves pre-kindergarten- $5^{\text {th }}$ graders and is comprised of about 800 students; $92 \%$ of students were of color during the 2012-2013 academic year, almost one-quarter are English Language Learners, and 85\% receive free or reduce priced lunch. Students live in the local community and are required to wear uniforms. The urban school is housed in an older building on a busy street, a mile away from the local high school.

Given the original purpose of the study, the first author (Elyse) visited the principal of the school to obtain consent and discuss nominations of teachers we might approach. Elyse explained to the principal that we were seeking teachers who 1) obtained repeated measures of high academic student performance; 2) held high expectation of students; 3) demonstrated successful approaches to working with challenging behavior; and 4) worked with general This is an Author's Original Manuscript of an article published by Taylor \& Francis in Action in Teacher Education on 09 Dec 2016, available online: http://www.tandfonline.com/10.1080/01626620.2016.1226206. 
education students with a wide range of academic levels. The principal nominated three teachers: Magdi, Renee, and Sally (pseudonyms). All three agreed to participate at the beginning but midway, Sally withdrew from the study. Therefore, our findings are based on the data from Magdi and Renee, two fifth-grade teachers. They mostly taught students of color from low-income families, many of whom had recently immigrated to the U.S. A number of students' primary caretakers were extended family members such as grandparents, aunts, and uncles. Both have only taught in urban, low-income schools, teaching nine and nineteen years, respectively.

Madgi, a White woman raised in a middle class family, grew up with five siblings. Even though Magdi lived with her parents, she recalls her grandmother playing an important role in her upbringing by taking her and her siblings to and from school every day, preparing meals, and ensuring that they completed their homework. For many years, her grandmother helped her parents raise their six children. Magdi began a master's degree in education in 2006 because she wanted to "expand [her] knowledge base... [and] was thirsty for more" (M-I1). She explained that she wanted to have additional knowledge of different teaching practices, hoping to gain a broader perspective. In her master's program, she recalled an inquiry project in which she chose to understand the perspectives of six of her Black and Latino students who lived in poverty. She believed her graduate work helped her to understand the complex challenges her students faced on a daily basis and prompted her to rethink her tacit assumptions about her students.

Renee, a Black woman, grew up in a working class family of seven siblings, raised primarily by her mother who was a school music teacher. She attended church every Sunday as a child, and sang and played piano in the church's choir. Wanting to "touch some souls," (R-I1), she left a career in business to teach because she felt that being a manager gave her little reward. As a Black person, she readily acknowledged racism as part of her lived experience and shared This is an Author's Original Manuscript of an article published by Taylor \& Francis in Action in Teacher Education on 09 Dec 2016, available online: http://www.tandfonline.com/10.1080/01626620.2016.1226206. 
her struggles of raising two Black teenagers whose teachers "don't know how to tap into their interests...I have a Black son who is misunderstood" (R-I1). The political clarity that guided her interactions with her biological children extended to her work with her students.

\section{Data Collection}

Formal interviews, informal interviews, and observations were the main sources of data. We opted to conduct interviews in conjunction with observation because they provide an indepth exploration of participants' perspectives and practices on what was observed (Hatch, 2002). Three formal semi-structured interviews were conducted with each teacher to understand how they enacted care for their students. On average, each interview lasted about one hour and took place after school. Audio files were transcribed verbatim.

We conducted observations for three months and paid close attention to dimensions such as the teacher's expectations, her urgency, and both verbal and non-verbal language.

Observations were accomplished through frequent observation and we used field notes to record what we observed (Spradley, 1980) — 14 visits with each teacher lasting at least two hours each. The field notes then allowed us to find patterns in the teachers' behavior and prompted us to ask specific questions during informal interviews about their caring. Although observation raises the concern that participants will act in ways they think the researcher wants to see, prolonged minimized this issue. After most of the observations, we asked each teacher informal interview questions in order to clarify the practices we had observed. For example, when Renee frequently said to her students, "Get your head in the game," we asked her why she said this and what it meant. As researchers, we assumed a non-participant observer role; therefore, while did not hide our presence, we did not take an active role in the classroom (Wolcott, 1999).

\section{Data Analysis}

This is an Author's Original Manuscript of an article published by Taylor \& Francis in Action in Teacher Education on 09 Dec 2016, available online: http://www.tandfonline.com/10.1080/01626620.2016.1226206. 
We analyzed the data using constructivist grounded theory guidelines (Charmaz, 2006) because this approach highlights the shared experiences between the researchers and participants as a means of understanding how Magdi and Renee enact CRCTC for their students. First, we read all the interviews and field notes to develop initial codes. We used the teachers' words to create codes to avoid imposing our interpretation of the teachers' behavior. Our initial codes then led us to develop broader conceptual categories, what Charmaz refers to as focused codes. As an example, the initial codes "constant reminders," "pushing students," "redoing work," and “insisting," were connected to the larger focused code, "ways she holds high expectations." We then engaged in memo writing for each teacher, driven by the question "How does the teacher enact CRCTC for her students?" Memo writing revealed that the teachers engaged in similar practices, yet enacted these practices differently. For instance, both teachers worked to reconstruct students' identities by communicating that they believed in them however, Renee's approach also included students imagining themselves as successful in the future. The 12 memos we wrote prompted us to continue analyzing the focused codes, defining each larger codes' properties and characteristics, and raising the larger code to a conceptual level for further analysis. By comparing the memos, we were able to see the similarities and nuances in their perspectives and interactions with students. Our iterative and recursive process led us to go back and forth to actively engage with the data. For example, when Magdi referred to "student learning" as her goal for students, we returned to the data to define her meaning of the term with the following two questions in mind: What does student learning mean to her? What is she trying to accomplish with her students? We continued to refine conceptual categories to make analytical distinctions in frequent research meetings.

This is an Author's Original Manuscript of an article published by Taylor \& Francis in Action in Teacher Education on 09 Dec 2016, available online: http://www.tandfonline.com/10.1080/01626620.2016.1226206. 
We used several strategies to enhance trustworthiness. We engaged in member checking throughout the study by frequently checking descriptions and interpretations of the data with the teachers. We also conducted a final member checking email with each teacher to verify our datadriven representations of the teachers. The responses we received did not result in substantial changes but helped us to refine to our findings. As an example, Magdi chose to further elaborate on her overall goals for students and we included these statements in the findings. By collecting observation and interview data we were able to triangulate analysis and provide a detailed account of the findings. Peer debriefing with one another throughout the process of data analysis helped us by prompting discussion and ultimately leading us to consensus on findings.

\section{Researcher Positionality}

Our own experiences and beliefs undoubtedly shaped the way we approached this study.

We are teacher educators and researchers committed to improving equity and dismantling injustice in the context of urban and low-income schools. Moreover, we seek ways to prepare novices, who, like us, tend to have experienced the privileges of middle and upper middle class upbringings, to develop the commitments, knowledge, and practices required to be exemplary teachers of all children. We agree with Kumashiro (2009) who argues that "good" teaching, which is often regarded as "common sense," may actually reify hegemonic practices in schools. While assertions about "best practice" and "evidence-based practice" permeate national education discourse, these perspectives of what and how teachers should teach typically reflect the beliefs, values, and priorities of those whose views dominate in society. While there is certainly value in these research-based practices, we believe that research and knowledge are always partial and never neutral in their consequences (Kumashiro, 2009). Thus, we embrace the view that good teaching does not comprise a finite list of best practices because teaching and This is an Author's Original Manuscript of an article published by Taylor \& Francis in Action in Teacher Education on 09 Dec 2016, available online: http://www.tandfonline.com/10.1080/01626620.2016.1226206. 
learning are multifaceted, highly contextual, and value-laden. By valuing the knowledge and experience of teachers like Magdi and Renee, we can shine a light on effective practice for students who have a long history of being marginalized in school.

\section{Findings}

The findings reveal Magdi and Renee's educational philosophy and practice. It soon became clear that they did not perceive children's behavior as challenging; rather, they embraced their responsibility for preparing their students for a world that did not always value or support them. Magdi and Renee taught us about the skills they regarded as essential for their students and the ways they went about teaching these skills. We report here on their similar ideological orientation to teaching — and how this orientation guided their critical caring for students.

\section{Cultivating Flourishing Lives through Culturally Relevant Critical Teacher Care}

First, it is important to portray the teachers' ideological orientation to understand the commitments that fuel the enactment of CRCTC. Both Magdi and Renee created classroom spaces grounded in CRCTC to prepare their students for flourishing lives. We borrow this term from Grant (2012) who suggest that cultivating flourishing lives is undergirded by a commitment that

recognizes that, as democratic citizens and as humans, students are more than their test scores, their skill mastery, or their future employment. Instead, the commitment is to the "full development of the human personality" (United Nations, 1948, Article 26.2), that encourages all students - regardless of race, ethnicity, socioeconomic status, language, religion, or gender — to imagine and experience flourishing lives... for a commitment to students' flourishing lives is a commitment to their flourishing minds. (p. 25, italics in original)

This is an Author's Original Manuscript of an article published by Taylor \& Francis in Action in Teacher Education on 09 Dec 2016, available online: http://www.tandfonline.com/10.1080/01626620.2016.1226206. 
Magdi and Renee were committed to helping students to discover their strengths and aptitudes and pushing them to work on what they needed to improve. They believed that all students were capable of success and that it was their responsibility to nurture the development of students' flourishing lives. Success, for these teachers, was not only narrowly related to passing tests. Success meant that students had to develop dexterity in learning many skills that we elaborate on later in the paper. These were skills the teachers insisted that they teach their marginalized students, who have too often been denied opportunities to lead flourishing lives.

Empowering students to excel was fueled by the teachers' political clarity and a critical hope for a brilliant future for their students. As an African American woman who grew up in poverty, Renee and her family experienced racism of various kinds. For example, it was not unusual for people to make statements to her such as, "Oh you're not really Black" (R-I3). Renee explained that this remark sent an insidious message: "They think that all Black people are very poor and illiterate and not educated. That's exactly what they're saying to you" (R-I3). Renee recognized that her students would encounter similar comments: "You look at [my students'] family backgrounds, the struggles, and the challenges that their families have to go through. I tell my kids...I want you to be successful.'” (R-I1) Renee's political clarity acknowledged the world as inherently inequitable. If she did not enact CRCTC, "these students won't have a chance," she insisted.

Magdi admitted to a lack of political clarity in her beginning years as a teacher. She was a self-proclaimed dictator and talked about what she was like early in her career:

When I first started teaching...the kids were totally on task, quiet. I'm speaking, you're not. That's the way it goes. Collaborative groups? Them working in a center? That would drive me insane .... I was very much a dictator, very much in control of everyone's This is an Author's Original Manuscript of an article published by Taylor \& Francis in Action in Teacher Education on 09 Dec 2016, available online: http://www.tandfonline.com/10.1080/01626620.2016.1226206. 
behavior just by silencing them. It was like straight line, hands to your side, facing forward ... and every teacher would send their misbehaved children to my class like I was a dictator. (M-I3)

However, Magdi described a transformative shift from a dictator to a teacher who worked to become politically clear. In discussing the connection between her own awareness of students' lack of opportunities and her role in possibly preventing them from success, she revealed:

I mean, was I aware? Yes, I'm teaching high-poverty students and a lot of these students are in a position where they don't have opportunities that others have or they're looked at [by other teachers] like, 'We can never teach these students. We can never reach these students,' or they're compared to students that obviously have privileges that they have never been privy to. Yes, I have that awareness, from working with them day in and day out. But, was I able to recognize things that I might have been doing to contribute to that? No ... it took me stopping and going, 'Whoa, hold on, there are things that I might have been doing?' and not even recognized it. (M-I3)

Madgi believed that her graduate studies led her to uncover the assumptions she once made about who students were and what they needed without genuinely knowing them or their circumstances. Examining the assumptions that guided her interactions with students, she elaborated:

[I] assumed, poor them, this is what they need...but having no idea of their perspectives or their point of view or what they want from a teacher or what things that teachers do that affect them. I never stopped to ask the students, "What are some things that a teacher's said to you or done in the classroom that's really been so helpful? What hurts you? What makes you not really want to learn?" (M-I3)

This is an Author's Original Manuscript of an article published by Taylor \& Francis in Action in Teacher Education on 09 Dec 2016, available online: http://www.tandfonline.com/10.1080/01626620.2016.1226206. 
In this quote, we see Magdi moving away from universal assumptions of care to thinking about students' broader circumstances and understanding how they want to be cared for. Madgi and Renee enacted a justice-oriented conception of care driven by an urgency to provide subjugated students with a powerful education to enable them to improve their lives and the larger community.

\section{Enacting Culturally Relevant Critical Critical Care}

We organize Madgi and Renee's commitment to students' flourishing lives by enacting CRCTC into four main themes: nurturing the whole child, reconstructing students' identities, holding students to high expectations and removing barriers to success, and instructional urgency. Surely, these were not the only ways the teachers enacted critical care, but they are prominent themes that emerged from the data.

Nurturing the whole child. In an era of ever-changing education reform, student learning often refers to the standardized measurement of test scores as the measurement of success. For Madgi and Renee, this was too narrow a definition. Guided by the teachers' political clarity, improving both academic and life skills were necessary if students were to experience flourishing lives. Renee shared that her vision for students to "be independent and to be able to carry skills outside of the classroom because it's difficult...in any situation if they do not use critical thinking skills. I think my larger goal is also preparing them for the real world" (R-I2) Similarly, Madgi viewed her role was to "push learning past the textbooks" by "teaching them many skills, values, ways of thinking that will not only allow them to perform well on a test, but that they'll also be taking with them out into another class, home, social interactions, and careers" (Magdi, personal communication, March 3, 2013). This meant that she strove to make

This is an Author's Original Manuscript of an article published by Taylor \& Francis in Action in Teacher Education on 09 Dec 2016, available online: http://www.tandfonline.com/10.1080/01626620.2016.1226206. 
connections between academic skills and supporting their access to successful lives. She further explained:

As a teacher, I might be teaching vocabulary essentially, but I [teach] how and why we might choose certain words to use in different scenarios. We go into how those words can be switched around depending on whom I'm talking to ... what's more appropriate? So what seems like a synonym lesson ... quickly becomes a lesson that [students] consider the next time they have a conversation with an adult, or when they are in an interviewtype setting. (Magdi, personal communication, March 3, 2013)

The teachers believed it was their responsibility to prepare students for what was beyond school as an institution. This preparation included teaching students skills such as how to respect others, not to steal, and to persevere when things became difficult. When a student accidentally bumped into another student and yelled, "Yo, what's your problem?," Magdi intervened and firmly stated, "Excuse me? Is that how you speak to people? You need to take your time before you begin to speak" (M-O1105). Learning that a student stole candy from her desk, she walked to his house after school to have a conversation with him about why stealing was inappropriate (M-I2). In another example, when a student had difficulty with a question on a reading assignment, Magdi insisted that he reread the paragraph. Once he selected the correct answer, she smiled at him, placed her hand on his shoulder and reassured, "It might be a pain in the butt to have to read a paragraph three or four times, but doesn't it feel good to be sure that your answer is right?" He smiled back and thanked her (M-O1113). She acknowledged the difficulty and reminded students, “Just because it gets difficult you can't let the effort go. You HAVE to keep trying" (M-O1212).

This is an Author's Original Manuscript of an article published by Taylor \& Francis in Action in Teacher Education on 09 Dec 2016, available online: http://www.tandfonline.com/10.1080/01626620.2016.1226206. 
A vital skill that Renee hoped to nurture within her students was how to embrace others who were different from them. She knew that once they were adults in the world, they were going to interact with people who had different frames of reference and ways of being. During a lesson, she explained to students:

You have to work with various personalities — strong, passive, bossy personalities. But you know what it's called? It's called LIFE and you have to deal with it! If someone is bossy, is that a bad thing? Not necessarily. I have a very big mouth. Ms. Renee has a VERY big mouth. I can be very boisterous. I am LOUD! But guess what? I am also a very easy person to get along with, and that's just my personality. It's all about ACCEPTING people. (R-O112712)

She encouraged them to have a positive attitude and to view others from an asset-based perspective. Instead of viewing people as bossy, she urged them to reframe their thinking, helping them to see others in a positive light. She wanted them to embrace others' differences and learn to work with them in challenging situations. The teachers' ideological orientation engendered a responsibility for the collective wellbeing of humankind and thus, coaching students to value and respect others was paramount.

Reconstructing students' identities. Madgi and Renee enacted critical care by enabling students to become subjects rather than objects (Freire, 1970). That is, they wanted students to be self-determining and unconstrained by the low expectations others might have of them. When students entered their classrooms at the beginning of the year, many did not view themselves as capable of success because of the deficit labels they had internalized. Therefore, the teachers worked to reconstruct students' identities by explicitly communicating that they believed in them and by helping them to imagine themselves living flourishing lives.

This is an Author's Original Manuscript of an article published by Taylor \& Francis in Action in Teacher Education on 09 Dec 2016, available online: http://www.tandfonline.com/10.1080/01626620.2016.1226206. 
To help students see themselves in new ways, the teachers were clear to communicate that their students had the aptitude to excel. For example, when a student said he was fine with his overall grade of a C because "it means average," Magdi rebutted,

You think you're average?! You're not average. ... I don't raise my son just to be 'average.' I want him to excel; I want him to be the best he can possibly be, I want him to do his very best all the time and your grandparents and I feel the same way about you. They do not look at you and say, 'Oh, he's just an average boy.' They see you like I see you, that you're capable of getting straight A's. We want to put you in the gifted program. ... Nobody here thinks you're average, and you need to prove to us that we're all right. (M-I3)

Renee communicated similar messages. She explained to her students, "When you go out in the world, I want you to feel confident," (R-O1031). As she walked around the room during a lesson she said to individual students, "You're on fire!," "You're making progress," and "Ms. Renee is proud of you. You need to work harder because you're a champion" (R-O1031). By convincing students that they were capable, the teachers worked to reject their embodied deficit labels.

Renee in particular helped students imagine their future flourishing lives. Note how she achieved this:

Renee: Shaun, what do you aspire to be when you grow up?

Shaun: I want to be an architect.

Renee: Well imagine that you are a 24-year-old young architect and people are like 'Oh wow this guy is intelligent,' and people really respect his knowledge.' People might be intimidated but you're on top of the world, Shaun. (R-O1218)

This is an Author's Original Manuscript of an article published by Taylor \& Francis in Action in Teacher Education on 09 Dec 2016, available online: http://www.tandfonline.com/10.1080/01626620.2016.1226206. 
She also used the lyrics of a popular song on the radio to communicate the importance of improving one's community. In the following observation, Renee led the students in analyzing the lyrics of the song:

Renee: Okay, (points to one line in the song) what does that statement mean? What does that signify? THINK THINK! You are analyzing.

(Students give answers.)

Renee: Uh-huh. I'm so grounded but my head is in the clouds. We are making things happen here in the community we live in. We're on such a natural high. I can do anything I want to do.

Student: You mean there's is no stopping you?

Renee: Yes. There is no stopping you. (R-O1114)

Here, Renee conveyed to students that they had the skills and potential to enact change in their community. But students had to transform how they viewed themselves if they were to disrupt the status quo in their lives and communities.

Holding high expectations and removing barriers to success. As a teacher who proudly declared, "I have high expectations and students don't have a choice but to meet them" (M-I3), Magdi refused to accept anything less than students' best efforts. "They know I mean what I say and I'm consistent" (M-I1), she asserted in a business-like manner. This meant that when she stated an expectation, she followed through. Renee, too, held high expectations and believed that lowering expectations would only serve to undermine student achievement.

Magdi's care was manifested in her push for students to meet her expectations and to support them in the process of doing so: “There's constant work. It's not just, 'This is what I

This is an Author's Original Manuscript of an article published by Taylor \& Francis in Action in Teacher Education on 09 Dec 2016, available online: http://www.tandfonline.com/10.1080/01626620.2016.1226206. 
expect and that's it'" (M-I2). By developing relationships with students throughout the year, she was able to push:

The fact that I've had these conversations just means ... it's almost a reminder, 'Oh, yeah, Ms. Magdi. wants me to do this; she's not going to let me get away with not doing it.' So I mean because of the background and because of the foundation that I've set with them that I have these conversations and that I try and teach them and lead them there and then once I know they know better, I push them. (M-I3)

In this example, we see Magdi pushing students unyieldingly to make inferences from the text:

Can you prove that to me? Where is the evidence? Don't just point. Prove it to me! How am I going to show the EVIDENCE? We want just the answers, just the evidence, just the PROOF. You are going to go back in that story, and I expect to see where you found the answer with your highlighter. Let's go back and number our paragraphs so it's easy for me to find it later. (M-O1113)

Making inferences was a skill practiced from the beginning of the year. Therefore, when a student rushed to finish his reading assignment, she gave him a stern look and firmly said, "No, your inference does not have SPECIFIC evidence. You must be specific and draw conclusions from the text" (M-O1105). Returning his paper, she insisted that he go back and redo the assignment.

Similarly, it was not uncommon for Renee to ask students to redo an assignment or task when they did not do their best. During individual presentations, she expected students to speak clearly and confidently. When a student began to mumble about his project, she stopped him and said, "WAIT, WAIT, WAIT. What did I tell you guys? Talk from your diaphragm. Open your mouth and speak. You are not mumbling to us. You need to open your mouth and speak" (RThis is an Author's Original Manuscript of an article published by Taylor \& Francis in Action in Teacher Education on 09 Dec 2016, available online: http://www.tandfonline.com/10.1080/01626620.2016.1226206. 
O1115). Dissatisfied with the student's low volume, she demanded that the student start from the beginning.

Renee often said the phrase "get your head in the game!" to communicate her expectation that students would put all of their energy into the task at hand:

Renee: All right, guys, let's do it. We're gonna do what?

Students (in unison): Get our head in the game!!!

(One student is slouching in her seat.)

Renee: While you are in my class, you are not to slouch. Put your butt in the chair. You see, when you go and get a job and you're slouching, they're not gonna hire you. You need to sit up. (R-O1107)

Renee believed it was important for her students to get their "head in the game" as slouching or other behaviors such as putting their head on the table, might communicate disinterest or inattentiveness. She was explicit in her teaching about what would lead them to flourishing lives, and she cared for them by reminding them that they needed to be alert and ready to learn.

For Magdi, holding students to high expectations also included working to remove barriers that would hinder them from reaching expectations. For example, when a student's special reading chair broke, she sat on the carpet and tried to fix his chair. In doing so, she cut her finger and said, "See? I got a cut from trying to fix it. See that love and dedication I have for you?" (M-O1113). Coming to school was of upmost importance to Madgi, so when she learned that one of her students repeatedly missed school simply because he did not have a clean uniform, she instructed that he come to school with or without the uniform, telling him that she would not send him to the office if he did not come to school with a clean uniform. In this way, she would go against the school's policy that instructed teachers to send students to the office if This is an Author's Original Manuscript of an article published by Taylor \& Francis in Action in Teacher Education on 09 Dec 2016, available online: http://www.tandfonline.com/10.1080/01626620.2016.1226206. 
they were not wearing a uniform. When one of Magdi's students was ordered by the Department of Children and Families to go to foster care, she placed an application to become his foster mother. Although he did not end up living with Magdi, her actions demonstrated her deep commitment to the wellbeing of this student.

Instructional urgency. The teachers' sense of urgency to educate their students permeated the classroom. Magdi and Renee's urgency was linked to their understanding that as members of historically marginalized groups, there were many skills to teach their students and it was imperative for students to strive for success. This meant that it was important for students to complete tasks on time if they were going to cultivate students' flourishing lives. Magdi explained:

They do have to stay on task and they do have to know that in the real world there's going to be goals that you have to meet, there's going to be things you have to get done and if you waste too much time... you're not going to be able to do it. (M-I2).

There was no time to waste and students were expected to be task-focused. Every moment counted. Madgi and Renee were "consistently insistent" (Authors, 2013) and the observations below offer a snapshot of their urgency:

Magdi: What does our classroom Rule Number One say?

Student: (reads rule on the wall) Always be prepared.

Magdi: Right, and you are not prepared because prepared in here means that you have three sharpened pencils, and you are wasting time. So, quickly get it sharpened. (MO1105)

This is an Author's Original Manuscript of an article published by Taylor \& Francis in Action in Teacher Education on 09 Dec 2016, available online: http://www.tandfonline.com/10.1080/01626620.2016.1226206. 
Renee: Son, you need to hurry up because you are wasting instructional time. No, no, you are wasting time.

Renee: Class, sometimes you do not display a sense of urgency. It's as if I tell you to work on an assignment and some of you take five, ten minutes to get started. You need to have that rush. It needs to be very important to you. (R-O1127)

While there was never downtime, it is also important to note that the activities they planned for challenged students to think and be creative. In other words, "busy work" did not exist. If students completed an activity and had a few extra minutes, they read a book, completed a prior assignment that they had not yet finished, or used an instructional computer program. Their instruction was fast-paced, but not so quick that students became lost. When they observed what they perceived to be off-task behavior, the teachers insistently and respectfully redirected students to get back to work.

The teachers recognized racism and poverty as key hindrances to their students' ability to achieve flourishing lives and were committed to enacting CRCTC to improve their futures. Magdi and Renee saw their students as whole persons and tended to the many crucial aspects of their human development. The teachers enacted a rigorous kind of care that defied low expectations and embraced their students' great potential. With political clarity, hope, and respect for their students' assets, they served as "gate openers" rather than "gate keepers" (Koerner \& Hulsebosch, 1995).

\section{Discussion and Implications}

The beliefs and practices of two teachers who enacted culturally relevant critical care in an effort to enable their students to cultivate flourishing lives may encourage teachers and teacher educators to reconsider assumptions about care and its purposes. Our findings revealed This is an Author's Original Manuscript of an article published by Taylor \& Francis in Action in Teacher Education on 09 Dec 2016, available online: http://www.tandfonline.com/10.1080/01626620.2016.1226206. 
that Magdi and Renee's notions of care were active and value-driven. Specifically, they viewed care as the actions they took in the service of their students' lives. Their care, more a verb than a noun, was guided by a concern for students' futures that prompted them to nurture the whole child, reconstruct students' identities, hold students to high expectations and remove barriers to their success, and teach with urgency. Their understanding of the broader sociopolitical context that shapes students' lives, oppressing some while advantaging others, prompted care as a moral imperative. The findings show that many of the enactments of Magdi and Renee's care are consistent with the literature on exemplary Black teachers (Acosta, 2013; Foster, 1997; Beauboeuf-LaFontant, 1997; Siddle-Walker, 1993), exemplary teachers of Black students (Gay, 2010; Ladson-Billings, 1994), and Roberts' (2009, 2010) interview study of secondary teachers which led to the notion of CRCTC. The 56 hours of observation data collected in Magdi and Renee's classrooms enabled us to extend Roberts' work on CRCTC by illustrating what it may look like in practice with elementary students.

While teachers claim to and genuinely believe that they care for their students, the nature of the care they enact has consequences for their students. McIntyre's (1997) insights into the politically unclear caring of the preservice teachers she studied should give us pause:

rather than expressing anger and rage at children coming to school with no coats and 'not having' what 'they have,'... [their] discourse lack[s] a sense of urgency about the need to restructure educational institutions. [They] conceptualize the problem as being internal to their students" (p. 667).

An important difference between McIntyre's participants and ours is insight into the larger sociohistorical-political context in which the particulars of school events unfold. Our participants recognized that the children they served represented a long history of systematic disadvantaging This is an Author's Original Manuscript of an article published by Taylor \& Francis in Action in Teacher Education on 09 Dec 2016, available online: http://www.tandfonline.com/10.1080/01626620.2016.1226206. 
and that they would enter a world where they would continue to be challenged by an uneven playing field. The teachers' knowledge of the constraints upon their students' futures catalyzed their enactment of a particular kind of care designed to prepare them with the dispositions, knowledge, and skills to achieve flourishing lives. Their knowledge of the macro-contexts of schooling enabled them to avoid being "arrogant perceivers" (Frye, 1983) of their students, but instead, to place their students and their lives at the center of the teachers' practice. In the words of Fasching-Varner and Dodo Seriki (2012), the teachers were able to move beyond "seeing with their eyes wide shut." McIntyre's preservice teachers, on the other hand, despite their good intentions, continued to rely on their own, privileged experiences to interpret what they observed in their students; that is, they were arrogant perceivers. With eyes wide shut, it is not surprising to find what Hayes and Juarez (2012) asserted to be the case in the majority of U.S. teacher preparation programs: "There is no culturally responsive teaching spoken here."

Without examining their own positionality as (often) people who have benefited from systems designed to serve them well, teachers may continue to act as arrogant perceivers who believe it is their job to "save" certain groups of students from their lives and communities. We see glimpses of this in Magdi's interview data where she called herself a former dictator, who once pitied and made assumptions about how students should be taught. However, through interrogation of her own Whiteness and privilege during graduate coursework, she began to develop an understanding of how her assumptions and teaching practices may have communicated a lack of care. Magdi's history indicates that shifts in stance and practice are possible. How might this kind of shift be taken up by teacher educators? We suggest that they must first attend to their own education.

This is an Author's Original Manuscript of an article published by Taylor \& Francis in Action in Teacher Education on 09 Dec 2016, available online: http://www.tandfonline.com/10.1080/01626620.2016.1226206. 
Nearly 15 years ago, Cochran-Smith (2000) asserted, "It takes more than good intentions [to teach for social justice]. While we currently may have the ability to inspire, we have not demonstrated the capacity to educate a professorate who can prepare pre-service candidates to succeed in diverse settings" (p.117). More recently, Sleeter (2012) and others have declared that teacher education has made little progress in this regard. Although learning about "others" is certainly a component of this preparation, White teacher educators are increasingly recognizing the importance of examining themselves in order to study the taken-for-granted worldviews that shape their beliefs and practice (Adair, 2008; Cochran-Smith, 2003; Lensmire et al., 2013; Levine-Rasky, 2000; Sensoy \& DiAngelo, 2012). In fact, the importance of teacher educator self-analysis is repeatedly implied in the Association of Teacher Educators Standards for Accomplished Teacher Educators (2008), which state, "To develop capacity among socially, culturally, and linguistically diverse students, teachers first need to know their own cultures" (see Standard 2). In order to accomplish this goal with future teachers, teacher educators must "examine their own beliefs and contributions of life experiences" (see Standard 4). That is, teacher educators must study their own culture, including the significance of their race. In addition, teacher educators must turn their gaze outward to the often-overlooked web of context—historical, political, economic, cultural, legal—that shapes their beliefs and practices as human beings and teacher educators. Without doing both, they are unlikely to be successful in broadening their students' understandings of themselves and the larger context in which day-today decisions about teaching take place.

In communities of CRCTC students can be educated to pursue flourishing lives. Preparing teachers for this kind of work requires a particular kind of teacher education. CochranSmith (2003), Zeichner (2009) and others have insisted on teacher education for social justice; This is an Author's Original Manuscript of an article published by Taylor \& Francis in Action in Teacher Education on 09 Dec 2016, available online: http://www.tandfonline.com/10.1080/01626620.2016.1226206. 
that is, preparing teachers to go beyond celebrating diversity to opening gates for students and communities that historically have been marginalized. In order to address the education debt our country owes students of color (Ladson-Billings, 2006), teachers must be prepared to enact potent CRCTC. Magdi and Renee's stories provide portraits of classroom spaces ripe for high quality teaching, learning, and liberation of students of color. They also provide a resource for teacher educators who are eager to engage in critical reflection and action to accomplish excellence and equity in elementary education.

\section{References}

Acosta, M. (2013). A Culture-focused Study With Accomplished Black Educators on Pedagogical Excellence for African American Children. Unpublished doctoral dissertation. Gainesville, FL: University of Florida.

Adair, J. (2008). White pre-service teachers and" de-privileged spaces." Teacher Education Quarterly, 35(4), 189-206.

Applebaum, B. (2010). Being white, being good. Lanham, MD: Rowman \& Littlefield.

Association of Teacher Educators Standards for Accomplished Teacher Educators (2008) http://www.ate1.org/pubs/uploads/tchredstds0308.pdf

Authors (2013).

Bartolome, L. (2009). Beyond the methods fetish: Toward a humanizing pedagogy. In A. Darder, M.P. Baltodano, \& R.D. Torres (Eds.). The critical pedagogy reader ( $2^{\text {nd }}$ ed.), pp. 338355. New York and London: Routledge.

This is an Author's Original Manuscript of an article published by Taylor \& Francis in Action in Teacher Education on 09 Dec 2016, available online: http://www.tandfonline.com/10.1080/01626620.2016.1226206. 
Beauboeuf-LaFontant, T. (1997). Politicized mothering among African American women teachers: A qualitative inquiry. Unpublished doctoral dissertation. Cambridge: Harvard Graduate School of Education.

Beauboeuf-LaFontant, T. (1999). A movement against and beyond boundaries: "Politically relevant teaching" among African American teachers. Teachers College Record, 100 (4), $702-723$.

Beauboeuf-LaFontant, T. (2002). A womanist experience of caring: Understanding the pedagogy of exemplary black women teachers. The Urban Review, 34 (1), 71-86.

Beauboeuf-LaFontant, T. (2005). Womanist lessons for reinventing teaching. Journal of Teacher Education, 56(5), 436-445.

Case, K. (1997). African American othermothering in the urban elementary school. The Urban Review, 29(1), 25-39.

Charmaz, K. (2006). Constructing grounded theory: A practical guide through qualitative analysis. Thousand Oaks, CA: Sage.

Comber, B. \& Kamler, B. (2004). Getting out of deficit: Pedagogies of reconnection. Teaching Education, 15(3), 293-310.

Civil Rights Data Collection (2012). A snapshot of opportunity gap data [Fact Sheet]. Retrieved from http://www2.ed.gov/about/offices/list/ocr/docs/crdc-2012-datasummary.pdf.

Cochran-Smith, M. (2000). Blind vision: Unlearning racism in teacher education. Harvard Educational Review, 70(2), 157-190.

Crotty, M. (1998). The foundations of social research. London: Sage.

Cochran-Smith, M. (2003). Learning and unlearning: The education of teacher educators.

This is an Author's Original Manuscript of an article published by Taylor \& Francis in Action in Teacher Education on 09 Dec 2016, available online: http://www.tandfonline.com/10.1080/01626620.2016.1226206. 
Teaching and Teacher Education, 19(1), 5-28.

Darder, A. (2015). Freire and education. New York and London: Routledge.

Darling-Hammond, L. (2008). Teaching and learning for understanding. In Barron, B., Pearson, P. D., Schoenfeld, A. H., Stage, E. K., Zimmerman, T. D., Cervetti, G. N., \& Tilson, J. L. (Eds.). Powerful learning: What we know about teaching for understanding (pp. 193211). San Francisco: Jossey-Bass.

Delpit, L. (1995). Other people's children: Cultural conflict in the classroom. New York: The New Press.

Duncan-Andrade, J. (2009). Note to educators: Hope required when growing roses in concrete. Harvard Educational Review, 79, 181-194.

Emmer, E. T., Evertson, C. M., \& Anderson, L. M. (1980). Effective classroom management at the beginning of the school year. The Elementary School Journal, 80(5), 219-231.

Fasching-Varner, K.J. \& Dodo Seriki, V. (2012). Moving beyond seeing with our eyes wide shut. Democracy and Education, 20 (1), Article 5.

Foster, M. (1997). Black teachers on teaching. New York: The New Press.

Freire, P. (1970). Pedagogy of the oppressed. New York: Continuum.

Freire, P. (1985). The politics of education: Culture, power, and liberation. South Hadley, MA: Bergin \& Garvey.

Freire, P. (2002). Pedagogy of hope. New York: Continuum.

Frye, M. (1983). The politics of reality: Essays in feminist theory. Trumansburg, NY: The Crossing Press.

This is an Author's Original Manuscript of an article published by Taylor \& Francis in Action in Teacher Education on 09 Dec 2016, available online: http://www.tandfonline.com/10.1080/01626620.2016.1226206. 
Gay, G. (2010). Culturally responsive teaching: Theory, research, and practice ( $\left.2^{\text {nd }} \mathrm{ed}.\right)$. New York: Teachers College Press.

Gomez, M. L. Allen, A. R. \& Clinton C. (2004). Cultural models of care in teaching: A case study of one pre-service secondary teacher. Teaching and Teacher Education, 20(5), 473-488.

González, N., Moll, L., \& Amanti, C. (2005). Funds of knowledge: Theorizing practices in households, communities and classrooms. Mahwah, NJ: Erlbaum.

Gorski, P. (2011). Unlearning deficit ideology and the scornful gaze: Thoughts on authenticating the class discourse in education. Counterpoints, 402, 152-173.

Gorski, P. (2014). Reaching and teaching students in poverty. New York: Teachers College Press.

Grant, C. (2012). Cultivating flourishing lives: A robust social justice vision of education. American Educational Research Journal, 49(5), 910-934.

Hatch, J. A., (2002). Doing qualitative research in education settings. Albany, NY: State University of New York Press.

Hayes, C. \& Juarez, B. (2012). There is no culturally responsive teaching spoken here: A critical race perspective. Democracy and Education, 20(1), Article 1.

Irvine, J.J. (2001). Caring, competent teachers in complex classrooms. Charles W. Hunt Memorial Lecture. $53^{\text {rd }}$ annual meeting of the American Association of Colleges of Teacher Preparation. Washington, DC: AACTE Publications.

Irvine, J. J. (2002). In search of wholeness: African American teachers and their culturallyspecific classroom practices. New York: Palgrave.

This is an Author's Original Manuscript of an article published by Taylor \& Francis in Action in Teacher Education on 09 Dec 2016, available online: http://www.tandfonline.com/10.1080/01626620.2016.1226206. 
Koerner, M. \& Hulsebosch, P. (1995, February). Teaching to give students voice in the college classroom. Paper presented at the Annual Meeting of the Association of Teacher Educators, Detroit, MI.

King, J. E. (1991). Dysconscious racism: Ideology, identity, and the miseducation of teachers. Journal of Negro Education, 60(20), 133-146.

Koro-Ljungberg, M., Yendol-Hoppey, D., Smith, J. J., \& Hayes, S. B. (2009). (E)pistemological awareness, instantiation of methods, and uninformed methodological ambiguity in qualitative research projects. Educational Researcher, 38(9), 687-699.

Kumashiro, K. (2009). Against common sense: Teaching and learning toward social justice. NewYork: Routledge.

Ladson-Billings, G. (1994). The dreamkeepers: Successful teachers of African American children. San Francisco: Jossey-Bass.

Ladson-Billings, G. (2006). From achievement gap to education debt: Understanding achievement in US schools. Educational Researcher, 35(7), 3-12.

Lensmire, T.J., McManimon, S.K., Tierney, J.D., Lee-Nichols, M.E., Casey, Z.A., Lensmire, A., Davis, B.M. (2013). McIntosh as synedoche: How teacher education's focus on white privilege undermines antiracism. Harvard Educational Review, 88(3), 410-431.

Levine-Rasky, C. (2000). The practice of whiteness among teacher candidates. International Studies in Sociology of Education, 10(3), 263-284.

Lewis, C. C., Schaps, E., \& Watson, M. S. (1996). The caring classroom's academic edge. Educational Leadership, 54(1), 16-21.

McIntyre, A. (1997). Constructing an image of a white teacher. Teachers College Record, 98(4),

This is an Author's Original Manuscript of an article published by Taylor \& Francis in Action in Teacher Education on 09 Dec 2016, available online: http://www.tandfonline.com/10.1080/01626620.2016.1226206. 
653-681.

Milner, H. R. (2006). The promise of Black teachers' success with Black students. Educational Foundations, 20, 89-104.

Murrell, P.C. (2001). The community teacher: A new framework for effective urban teaching. New York: Teachers College Press.

Noblit, G. (1993). Power and caring. American Educational Research Journal, 30(1), 23-28.

Noddings, N. (1984). Caring: A feminine approach to ethics and moral education. Berkeley: University of California Press.

Noddings, N. (1992). The Challenge to Care in Schools. New York: Teachers College Press.

Noddings, N. (2002). Educating moral people: A caring alternative to character education. New York: Teachers College Press.

Noddings, N. (2013). Education and democracy in the 21st century. New York: Teachers College Press.

Rios-Aguilar, (2010). Measuring funds of knowledge: Contributions to Latino/a students' academic and nonacademic outcomes. Teachers College Record, 112 (8), 2209-2257.

Roberts, M.A. (2009). African American, European American, or does it make a difference? Teacher perceptions of care for African American students. Unpublished doctoral dissertation. Atlanta: Emory University.

Roberts, M. A. (2010). Toward a theory of culturally relevant critical teacher care: African American teachers' definitions and perceptions of care for African American students. Journal of Moral Education, 39(4), 449-467.

This is an Author's Original Manuscript of an article published by Taylor \& Francis in Action in Teacher Education on 09 Dec 2016, available online: http://www.tandfonline.com/10.1080/01626620.2016.1226206. 
Rolón-Dow, R. (2005). Critical care: A color(full) analysis of care narratives in the schooling experiences of Puerto Rican girls. American Education Research Journal, 42(1), pp. 77-111.

Sensoy, Ö., \& DiAngelo, R. J. (2012). Is everyone really equal?: An introduction to key concepts in social justice education. New York: Teachers College Press.

Siddle-Walker, V. (1993). Interpersonal caring in the "good" segregated schooling of African American children: Evidence from the case of Caswell County Training School. The Urban Review, 25(1), 63-77.

Sleeter, C. E. (2004). Context-conscious portraits and context-blind policy. Anthropology and Education Quarterly, 35(1), 12-136.

Sleeter, C. E. (2012). Confronting the marginalization of culturally responsive pedagogy. Urban Education, 47(3), 562-584.

Spradley, J. (1980). Participant observation. New York: Holt, Rinehart, and Winston.

United Nations (1948). The universal declaration of human rights. Retrieved from http://www.un.org/en/universal-declaration-human-rights/

Thompson, A. (1998). Not the color purple: Black feminist lessons for educational caring. Harvard Educational Review, 68(4), 522-554.

Valencia, R. (1997). The evolution of deficit thinking. London: Falmer Press.

Valencia, R. (2010). Dismantling contemporary deficit thinking: Educational thought and practice. New York and London: Routledge.

Ware, F. (2006). Warm demander pedagogy: Culturally responsive teaching that supports a culture of achievement for African American students. Urban Education, 41(4),

This is an Author's Original Manuscript of an article published by Taylor \& Francis in Action in Teacher Education on 09 Dec 2016, available online: http://www.tandfonline.com/10.1080/01626620.2016.1226206. 
427-456.

Welch, S. (1990). A feminist ethic of risk. Minneapolis: Fortress Press.

Wolcott, H. F. (1999). Ethnography: A way of seeing. Walnut Creek, CA: Altamira Press.

Yosso, T. (2006) Whose culture has capital? A critical race theory discussion of community cultural wealth. Race, Ethnicity and Education, 8(1), 69-91.

Zeichner, K. (2009). Teacher education and the struggle for social justice. New York and London: Routledge.

This is an Author's Original Manuscript of an article published by Taylor \& Francis in Action in Teacher Education on 09 Dec 2016, available online: http://www.tandfonline.com/10.1080/01626620.2016.1226206. 